University of Nebraska - Lincoln

DigitalCommons@University of Nebraska - Lincoln

1994

\title{
Herbicide Interchange between a Stream and the Adjacent Alluvial Aquifer
}

Wuncheng Wang

US. Geological Survey

Paul Squillace

US. Geological Survey

Follow this and additional works at: https://digitalcommons.unl.edu/usgsstaffpub

Part of the Earth Sciences Commons

Wang, Wuncheng and Squillace, Paul, "Herbicide Interchange between a Stream and the Adjacent Alluvial Aquifer" (1994). USGS Staff -- Published Research. 52.

https://digitalcommons.unl.edu/usgsstaffpub/52

This Article is brought to you for free and open access by the US Geological Survey at DigitalCommons@University of Nebraska - Lincoln. It has been accepted for inclusion in USGS Staff -- Published Research by an authorized administrator of DigitalCommons@University of Nebraska - Lincoln. 


\title{
Herbicide Interchange between a Stream and the Adjacent Alluvial Aquifer ${ }^{\dagger}$
}

\author{
Wuncheng Wang ${ }^{\circ}$ \\ U.S. Geological Survey, 720 Gracern Road, Suite 129, Columbia, South Carolina 29210 \\ Paul Squillace $¥$
}

U.S. Geological Survey, P.O. Box 1230, Iowa City, Iowa 52240

Herbicide interchange between a stream and the adjacent alluvial aquifer and quantification of herbicide bank storage during high streamflow were investigated at a research site on the Cedar River flood plain, $10 \mathrm{~km}$ southeast of Cedar Rapids, Iowa. During high streamflow in March 1990, alachlor, atrazine, and metolachlor were detected at concentrations above background in water from wells as distant as 20,50 , and $10 \mathrm{~m}$ from the river's edge, respectively. During high streamflow in May 1990, alachlor, atrazine, cyanazine, and metolachlor were detected at concentrations above background as distant as $20,50,10$, and $20 \mathrm{~m}$ from the river's edge, respectively. Herbicide bank storage took place during high streamflow when hydraulic gradients were from the river to the alluvial aquifer and the laterally infiltrating river water contained herbicide concentrations larger than background concentrations in the aquifer. The herbicide bank storage can be quantified by multiplying herbicide concentration by the "effective area" that a well represented and an assumed porosity of 0.25. During March 1990, herbicide bank storage values were calculated to be $1.7,79$, and $4.0 \mathrm{mg} / \mathrm{m}$ for alachlor, atrazine, and metolachlor, respectively. During May 1990 , values were $7.1,54,11$, and $19 \mathrm{mg} / \mathrm{m}$ for alachlor, atrazine, cyanazine, and metolachlor, respectively.

\section{Introduction}

Herbicide application has been an important management tool for agricultural production during the last 30 years. In the major corn (Zea mays L.) and soybean (Glycine max L.) production regions of the midwestern United States, several herbicides have been used extensively, including alachlor, atrazine, cyanazine, and metolachlor. They accounted for $72 \%$ of herbicide application in Iowa in 1990; the total herbicide usage exceeded $22000 \mathrm{t}$ of active ingredients (1).

These herbicides frequently have been detected in surface water (2-4). For example, during May and June 1991, every river water sample from agriculturally productive watersheds such as the White River in Indiana, the Illinois River in Illinois, and the Platte River in Nebraska contained $1.0 \mu \mathrm{g} / \mathrm{L}$ or larger concentrations of alachlor, atrazine, cyanazine, and metolachlor (3).

The fate and transport of herbicides in a river are complex and may include adsorption, photolysis, oxidation, microbial degradation, transport out of the system, and temporary storage in riverbanks. The bank storage of river water is well understood (5). Herbicide bank storage, although probably a widespread phenomenon, has been investigated only recently $(2,6-8)$. Squillace et al. (8)

\footnotetext{
+ The study was performed while both authors were at USGS, Iowa City, IA.

* Author for all correspondence.

* Address after Oct 1, 1994: U.S. Geological Survey, 1608 Mt. View Rd, Rapid City, SD 57702.
}

observed that during base-flow conditions along a 116-km reach of the Cedar River, Iowa, a $75 \%$ increase in dissolved atrazine concentrations in river water was due to groundwater discharge from bank storage and the river bed.

The objectives of the present study were to investigate herbicide interchange between a stream and the adjacent alluvial aquifer and to quantify herbicide bank storage during high streamflow. Storage beneath the river bottom was not investigated. The focus of the research was herbicide interchange during high streamflow (when the river stage increased but did not overtop the riverbank) and during floods (when the flood plain was inundated).

\section{Experimental Details}

Research Site. The research site was a wooded flood plain of the Cedar River near Palisades State Park, Iowa, approximately $10 \mathrm{~km}$ southeast of Cedar Rapids (Figure 1). The surficial geology of the site consists of fine- to coarse-grained sand overlying glacial till as shown in the figure.

During the spring of 1989 , monitoring wells were constructed at the research site in a line perpendicular to the river. They were located at $5,10,20,30$, and up to 320 $\mathrm{m}$ from the river's edge as shown in Figure 1 . The poly(vinyl chloride) well casings $(5.1 \mathrm{~cm}$ inside diameter) were cleaned using detergent and rinsed with deionized water before installation. Well screens (91 cm length) were installed $3,4,6,9$, or $14 \mathrm{~m}$ below land surface in most of well sites. A staff gage was used to measure river stage.

Water Samples. The study started May 1989 and ended July 1991. During base-flow periods, monthly samples of river and well water were collected. During high streamflow and flood periods, samples of river and well water were collected daily, using a depth-integrated sampler and a submersible pump, respectively. For well water, three times the casing volume of water was pumped out before samples were taken. River and well waters for herbicide analysis were filtered on site, using membrane filters of pore size $0.45 \mu \mathrm{m}$. Water samples were stored in 1-L baked-glass bottles with Teflon-lined caps at $4^{\circ} \mathrm{C}$. Herbicides (alachlor, atrazine, cyanazine, metolachlor, propazine, and simazine) and herbicide metabolites (desethylatrazine and desisopropylatrazine) were processed through solid-phase extraction cartridges and determined using gas chromatography/mass spectrometry according to the method described by Thurman et al. (9). Other herbicides such as ametryn, metribuzin, prometon, prometryn, simazine, and terbutryn were also determined. The detection level for herbicides was $0.05 \mu \mathrm{g} / \mathrm{L}$, except the detection level for cyanazine was $0.2 \mu \mathrm{g} / \mathrm{L}$.

\section{Results}

Quality Control. The blank, duplicate, and spikedwater samples used for quality control accounted for approximately $10 \%$ of all samples. Herbicides were not 


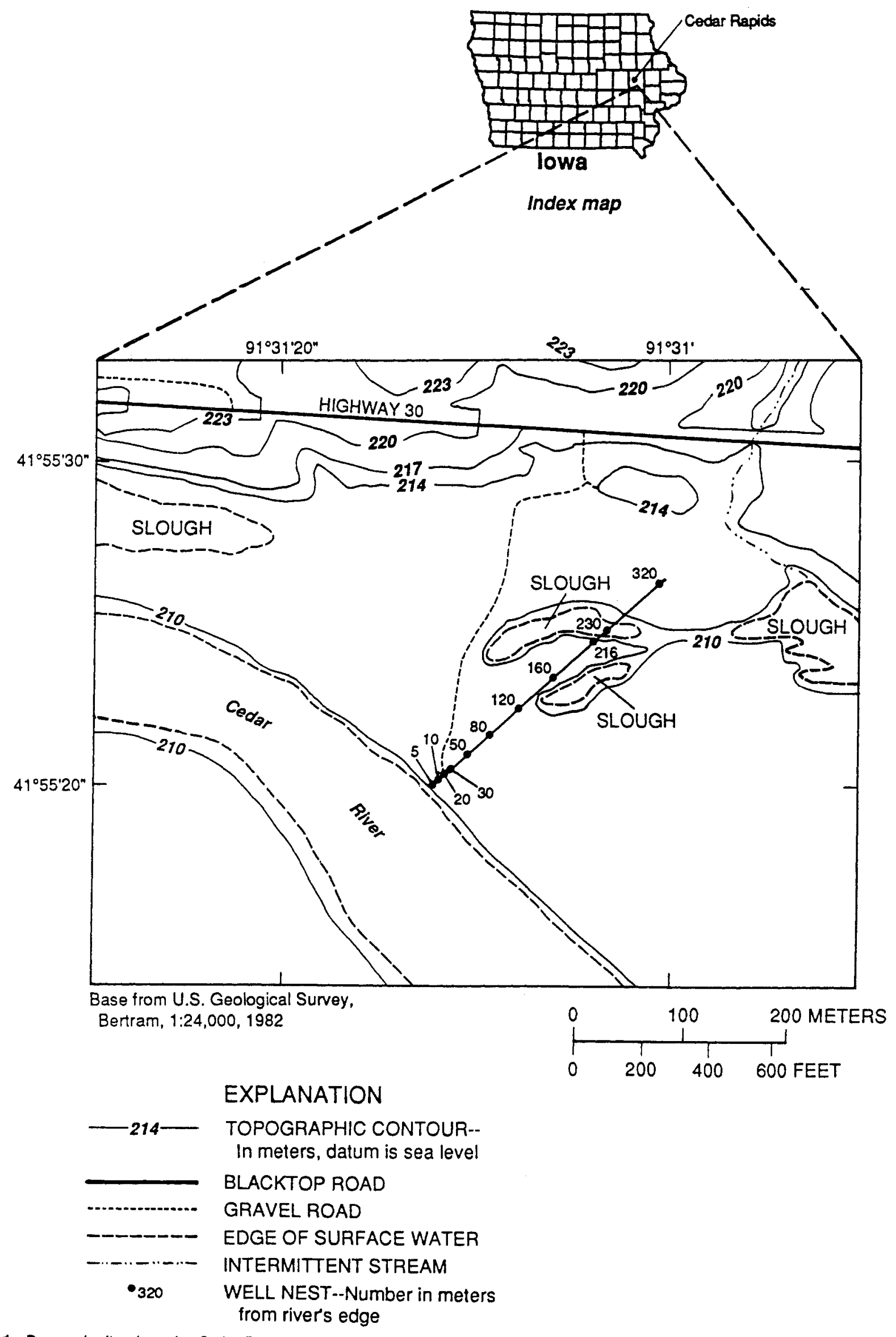

Figure 1. Research site along the Cedar River near Cedar Rapids, IA.

detected in any blank sample. The coefficients of variation of atrazine and desethylatrazine concentrations in 13 sets of duplicate samples were 3.7 and $7.1 \%$, respectively. The recovery of spiked samples was nearly $100 \%$ (10).
Base-Flow Condition, February 1990. The distribution of herbicides in the alluvial aquifer during February 20-22, 1990, was typical of base-flow conditions in the river (Figure $2 \mathrm{~A}$ ). The hydraulic gradient was from the 


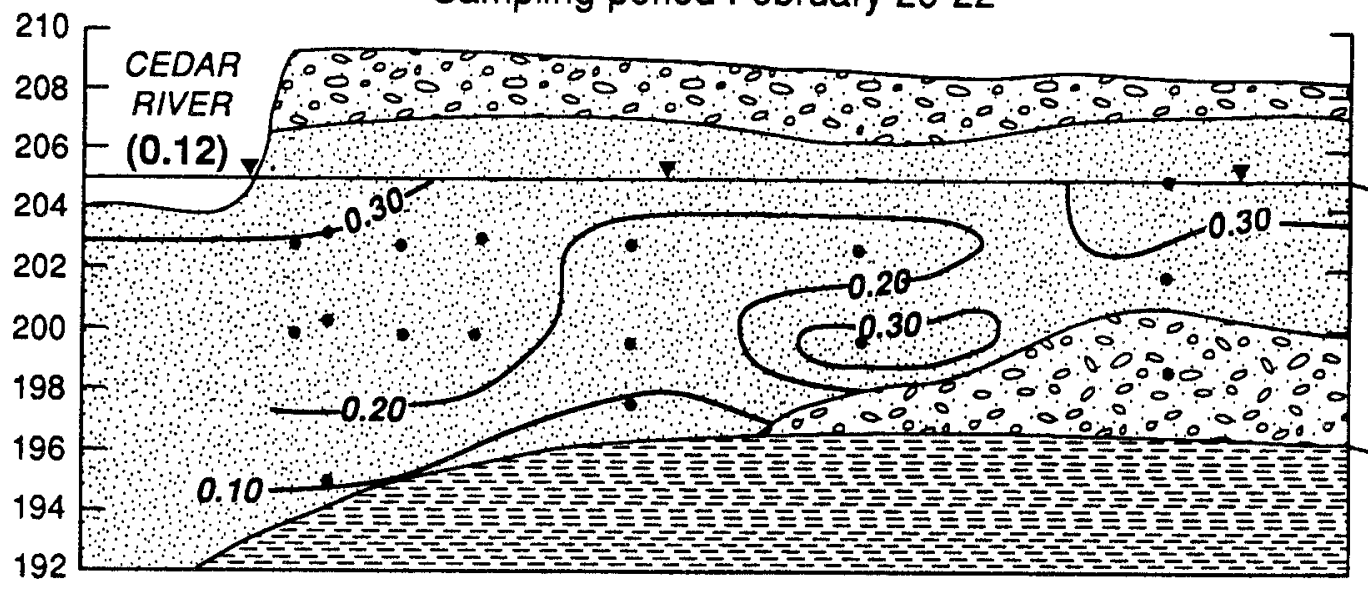

Water

Table

B. Sampling period March 20-22

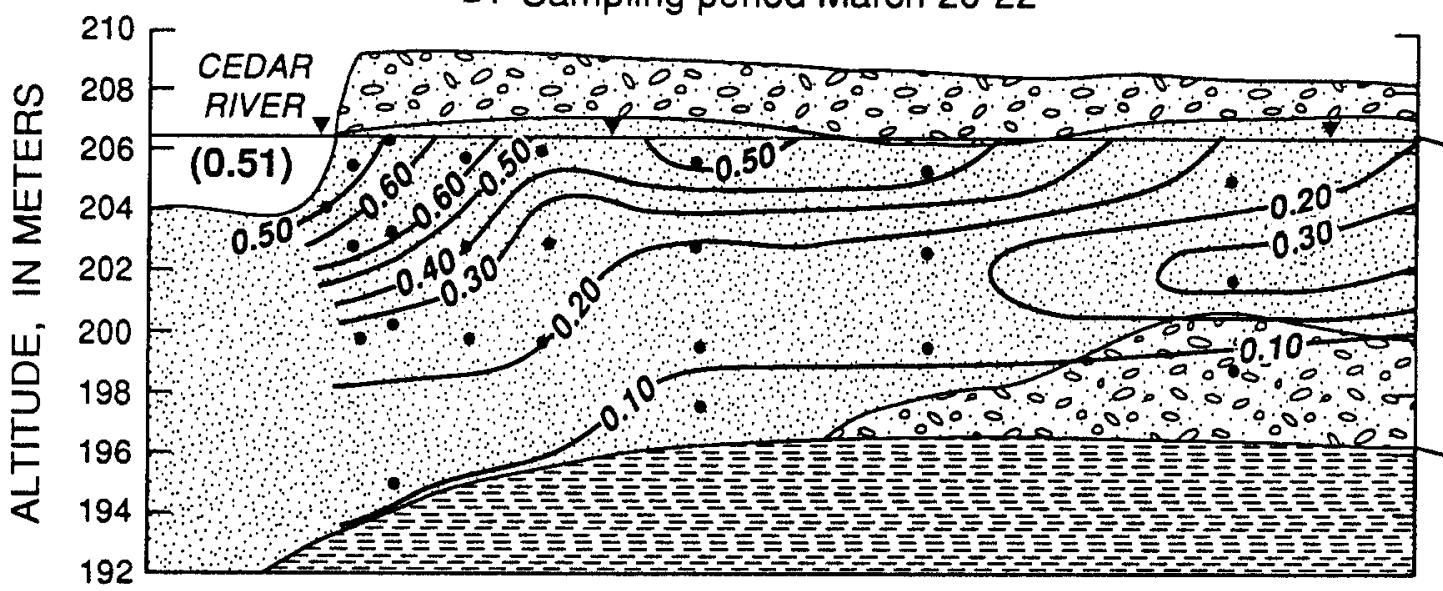

Water

Table

C. Sampling period April 3-5

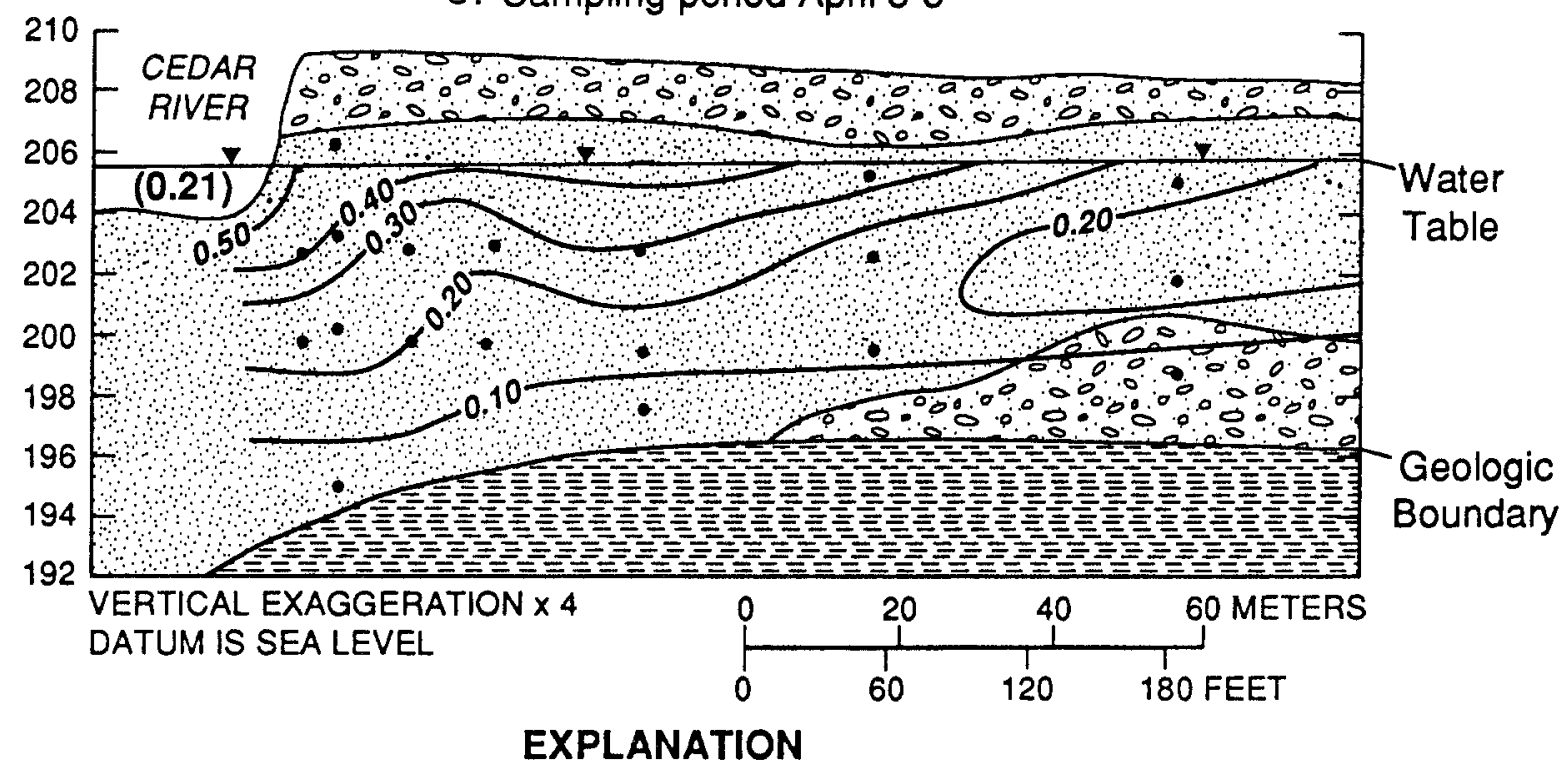

FINE-TO COARSE-GRAINED
SILTY/CLAYEY SAND
FINE-TO COARSE-GRAINED
SAND

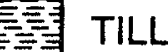

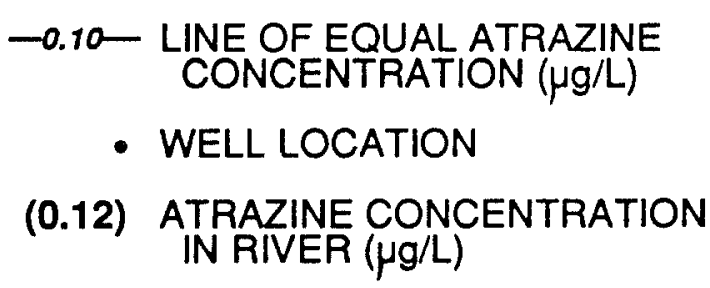

Flgure 2. Atrazine concentrations in water from the Cedar River alluvium, late February through early April 1990.

aquifer to the river. Atrazine concentrations were stratified, with the largest concentrations near the land surface. The atrazine metabolite desethylatrazine (not shown) was distributed more uniformly, with a median concentration for all wells and depths (54 samples) of $0.13 \mu \mathrm{g} / \mathrm{L}$. Concentrations of other herbicides (ametryn, metribuzin, 
A. Hydraulic gradient and river stage

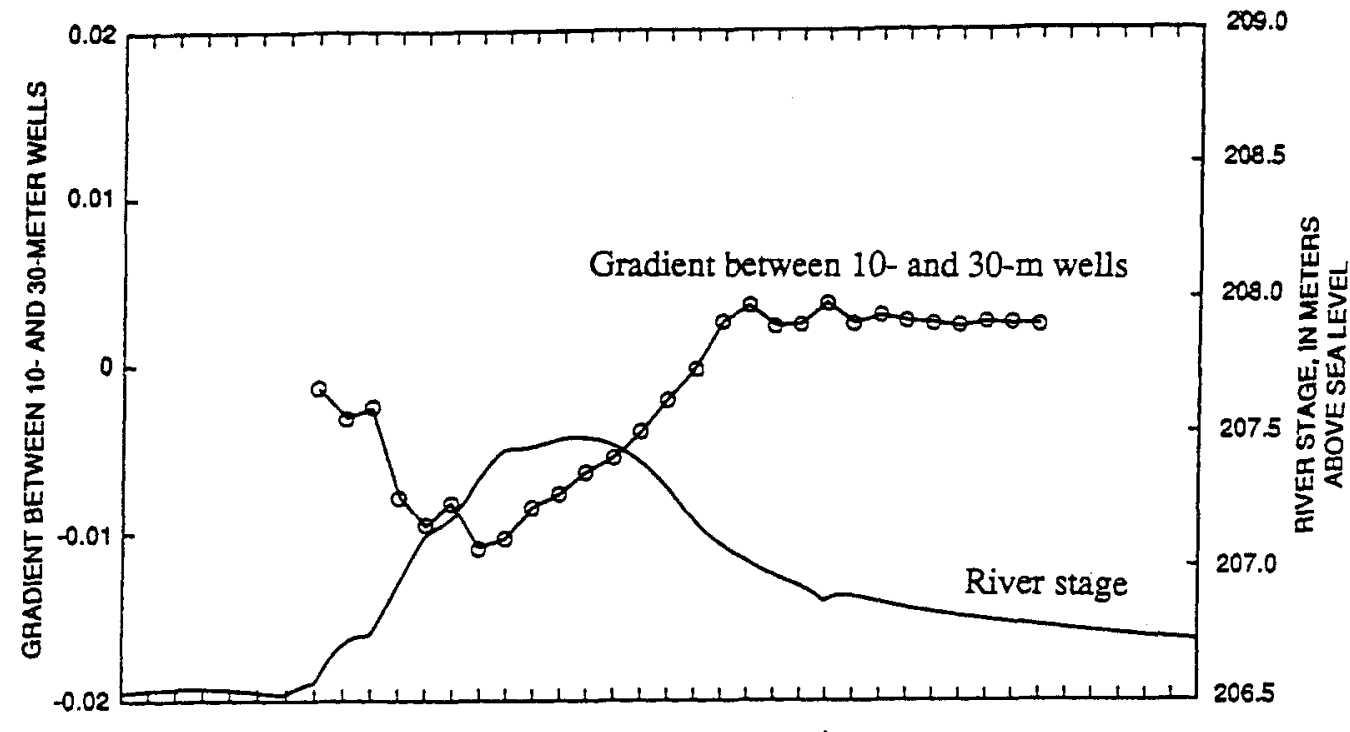

B. Atrazine concentration

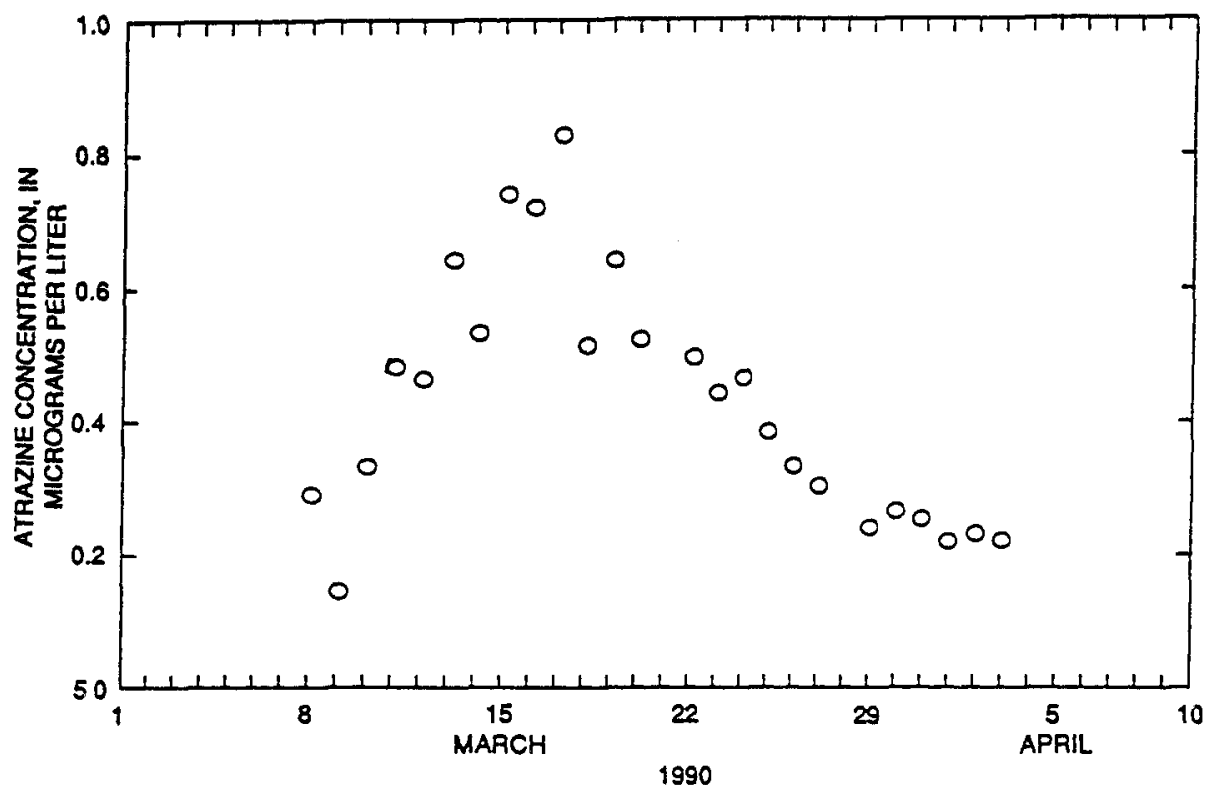

Flgure 3. (A) Hydraulic gradient between 10- and 30-m wells, both screened at a depth of $6 \mathrm{~m}$, and river stage during high streamflow, March-April 1990. Positive gradient indicated that the groundwater movement was from the aquifer toward the river and negatlve, from the river to the aqulfer. (B) Atrazine concentrations in the river water during the same period.

prometon, prometryn, simazine, and terbutryn) and the atrazine metabolite desisopropylatrazine were lower than the detection level throughout the research site. Only one sample from one well $120 \mathrm{~m}$ from the river and screened $3 \mathrm{~m}$ below land surface contained $0.14 \mu \mathrm{g} / \mathrm{L}$ desisopropylatrazine. All herbicide and metabolite concentrations during this period are used as respective "background" to compare with those observed under high streamflow and flood conditions and to delineate the herbicide interchange between the stream and the adjacent alluvial aquifer.

High Streamflow, March 1990. High streamflow conditions began March 8, 1990, when snowmelt and rainfall combined to gradually increase the river stage which, however, did not overtop the riverbank. The river stage peaked March 17 and 18. Between March 8 and March 21, the hydraulic gradient (values between 0 and 0.01 ) was from the river toward the aquifer, as indicated by water-level measurements in the wells located 10 and $30 \mathrm{~m}$ from the river's edge. On March 22, the hydraulic gradient reversed, and ground water moved from the aquifer to the river.
During the March 1990 high streamflow, the river stage and atrazine concentrations in the river water peaked concurrently (Figures $3 \mathrm{~A}, \mathrm{~B}$ ). Other compounds exhibiting the similar pattern were alachlor, metolachlor, and desethylatrazine. Cyanazine was detected in only 2 of 25 river water samples.

Atrazine concentrations in well water located $5 \mathrm{~m}$ from the river's edge at the depth of $6 \mathrm{~m}$ increased from 0.26 to $0.68 \mu \mathrm{g} / \mathrm{L}$ during late February to late March samples. The corresponding atrazine concentrations in river water samples were 0.12 and $0.51 \mu \mathrm{g} / \mathrm{L}$ (Figure 2A,B). In late March, atrazine concentrations greater than the background concentration were detected in wells as distant as $50 \mathrm{~m}$ from the river's edge and at a depth of $3-9 \mathrm{~m}$ below the land surface. The lines of equal atrazine concentration (Figure 2B) indicated a noticeable atrazine concentration gradient in the near-bank alluvial aquifer; the results suggest a substantial movement of atrazine from the river to the aquifer during this high streamflow period.

After March 22, the hydraulic gradient was from the aquifer to the river (Figure 3A). Atrazine concentrations 


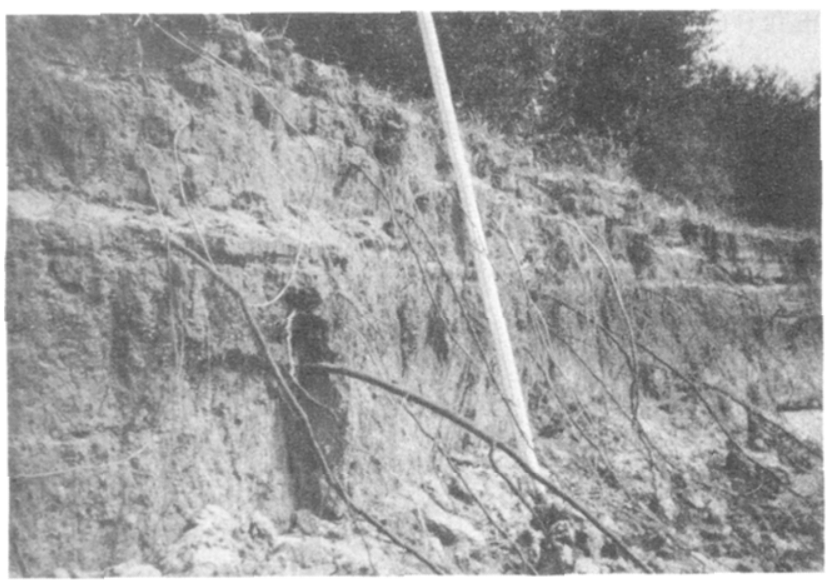

Figure 4. Tree roots exposed along the riverbanks at the research site.

in the river water decreased to $0.21 \mu \mathrm{g} / \mathrm{L}$ in early April (Figures $2 \mathrm{C}$ and $3 \mathrm{~B})$. Concurrently, atrazine concentrations in well water decreased from March to April (Figure $2 \mathrm{~B}, \mathrm{C})$, indicating that the herbicide was discharged into the river.

One possible factor contributing to the rapid herbicide interchange between the stream and the alluvial aquifer might be preferential flow through the well-developed riparian root system, which extends down to $3 \mathrm{~m}$ or more (Figure 4). The roots, especially dead or decayed roots, may provide lateral pathways for infiltrating river water, allowing rapid transport of herbicides into the alluvium.

High Streamflow, May 1990. Tne next high streamflow began in May 1990 and was more irregular than that in March (Figure 5). The river stage increased and decreased three times between May 10 and 29, and the hydraulic gradient fluctuated accordingly.

Results of herbicide analyses during May 1990 are given in Table 1. Larger concentrations of all herbicides in river water were detected during this period compared with those from the March 1990 samples. For example, the atrazine concentration in the river water was $3.0 \mu \mathrm{g} / \mathrm{L}$ on May 23 (Table 1) and $0.51 \mu \mathrm{g} / \mathrm{L}$ during March 20-22 (Figure 2B). On May 23, alachlor, cyanazine, and metolachlor concentrations in the river water were also large $(5.0,2.6$, and $5.5 \mu \mathrm{g} / \mathrm{L}$, respectively) (Table 1 ).

Elevated concentrations of alachlor, atrazine, cyanazine, and metolachlor in well water were detected in wells as distant as $20,50,10$, and $20 \mathrm{~m}$ from the river's edge, respectively (Table 1 ). On the basis of atrazine results, it is speculated that river water infiltrated as distant as $50 \mathrm{~m}$ from the riverbank, with $3-6 \mathrm{~m}$ depth as the major pathway.

Flood, June 1990. During the flood, herbicide concentrations in water from almost all wells sampled, from 5 to $50 \mathrm{~m}$ from the river's edge and from 3 to $9 \mathrm{~m}$ in depth, did not exceed background concentrations during February 1990. In the same period, the hydraulic gradients were primarily toward the river (12 of 15 days determined) possibly due to rapid infiltration of floodwater into the shallow aquifer via the land surface.

The reason(s) that herbicides did not infiltrate from the land surface into the aquifer can be speculated. During the infiltration, the dissolved herbicides likely are removed through the established and active root zone in the study site $(11,12)$. Results of one study indicated that approximately 10 times more atrazine was removed from a system with poplar tree roots than from a root-free control site (12). In addition, it is likely that the large accumulation of plant debris, especially humic substances, at the land surface could have adsorbed herbicides or induced microbial degradation as floodwater infiltrated the aquifer (11). Consequently, sufficient floodwater infiltrated into the aquifer to maintain a hydraulic gradient toward the river, but dissolved herbicides in the well water did not increase above the background concentrations.

Large herbicide concentrations, however, were detected in well water far away from the river's edge. On June 27, 1990 , concentrations of atrazine, cyanazine, desethylatrazine, desisopropylatrazine, and metolachlor in water from a well $216 \mathrm{~m}$ from the river's edge and screened $3 \mathrm{~m}$ deep were $8.0,0.50,1.4,0.23$, and $2.7 \mu \mathrm{g} / \mathrm{L}$, respectively. The alachlor concentration was less than the detection level. The atrazine concentration, in particular, was about 40 times more than the background concentration of 0.20 $\mu \mathrm{g} / \mathrm{L}$. This phenomenon can be explained as follows.

The well $216 \mathrm{~m}$ from the river's edge is adjacent to a slough (Figure 1). The slough received runoff from upland areas above the flood plain through an intermittent stream, as shown in Figure 1. Large atrazine concentrations of 48 , $40,9.9$, and $3.0 \mu \mathrm{g} / \mathrm{L}$ were detected in water from the slough on May 25 and 29 and June 5 and 26, 1990, respectively. The intermittent stream also contained large atrazine concentrations: $62 \mu \mathrm{g} / \mathrm{L}$ was detected on May 19. For comparison, during May 16-31, daily atrazine concentrations in the river water ranged from 1.0 to $7.0 \mu \mathrm{g} / \mathrm{L}$. The herbicide concentrations in the slough were closer to the range in the intermittent stream water than those in the river water, and thus the runoff from the intermittent stream during this flood is considered the main source of herbicides in the slough. The runoff, once trapped in the slough, would have percolated continuously into the aquifer and, in the process, transported large concentrations of herbicides into the aquifer.

Flood, March and April 1991. During the 1990-1991 floods, approximately $8 \mathrm{~m}$ of the riverbank was eroded laterally. One new well was installed during the winter of 1990-1991, $12 \mathrm{~m}$ from the river's original edge and at a depth of $4 \mathrm{~m}$, to replace a damaged well nest. Concentrations of atrazine and desethylatrazine in river water and in well water during March and early April are plotted in Figure 6. Comparing results of the same dates, the atrazine concentrations in the well water were larger than in the river water. A possible explanation is that well water and river water samples, although collected on the same date, probably were not from the same mass of water. As sufficient hydraulic gradient is required for the river water to travel through the alluvial aquifer, the well water is assumed to be composed primarily of water from the rising stage. River water at rising stage has been reported to contain atrazine concentrations larger than river water at the falling stage (14). Desethylatrazine concentrations, in contrast, were similar in well and river water (Figure $6)$.

\section{Discussion}

Herbicide Basin Storage. Patterns of herbicide concentrations in the river water during high streamflow (May 1990) and flood (June 1990) are different. During the flood (June 26-27, 1990), concentrations of alachlor, atrazine, cyanazine, and metolachlor in river water were $0.37,3.8,0.67$, and $1.2 \mu \mathrm{g} / \mathrm{L}$, respectively, when the river's mean daily discharge was $458 \mathrm{~m}^{3} / \mathrm{s}$ (13). For comparison, during the high streamflow (May 28, 1990), the herbicide concentrations in river water samples were $0.86,1.0,0.87$, 


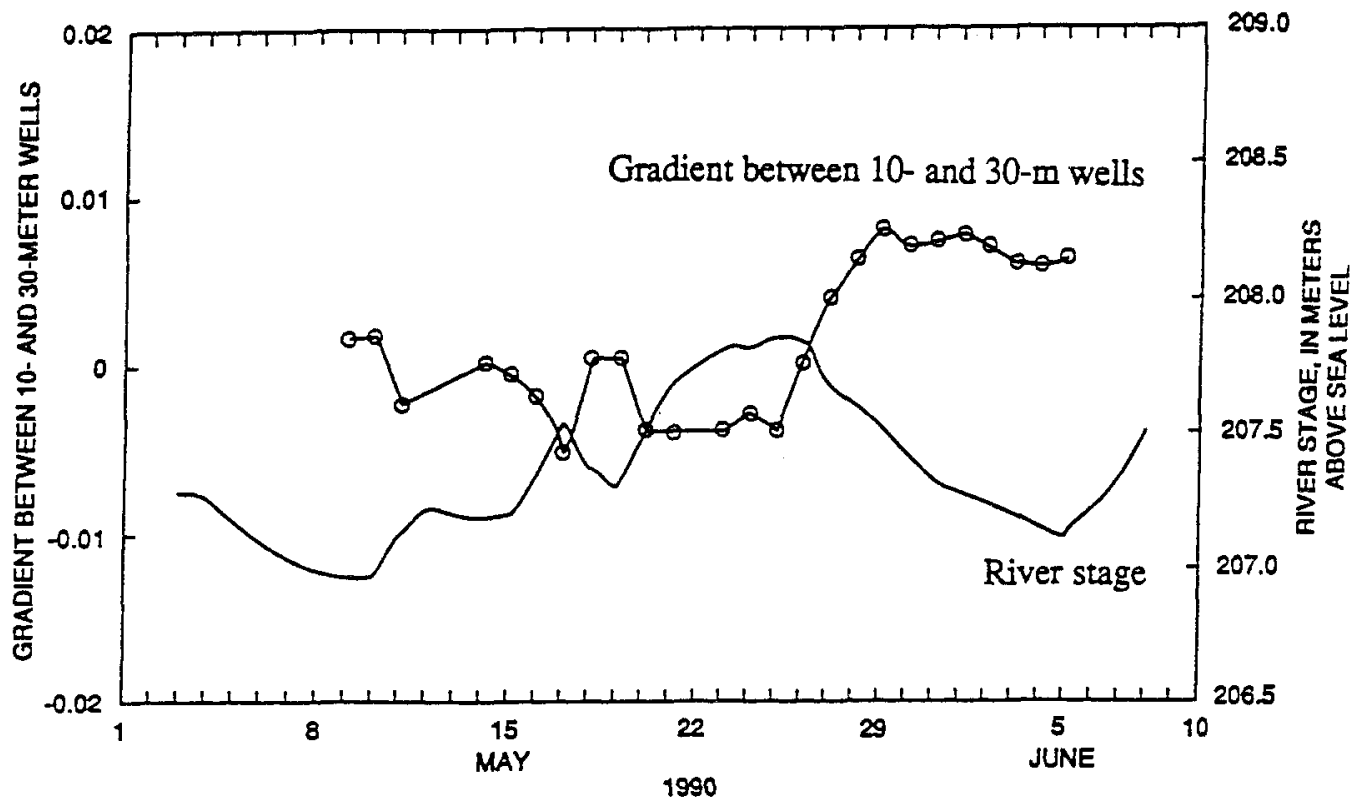

Figure 5. Hydraulic gradient between 10 - and $30-\mathrm{m}$ wells, both screened at a depth of $6 \mathrm{~m}$, and river stage during the high streamflow, May-June 1990. Positive gradient indlcated that the groundwater movement was from the aquifer toward the river and negative, from the river to the aquifer.

\begin{tabular}{|c|c|c|c|c|c|c|c|}
\hline \multicolumn{2}{|c|}{ river water } & \multirow[b]{2}{*}{$\begin{array}{c}\text { alachlor } \\
5.0\end{array}$} & \multirow[b]{2}{*}{$\begin{array}{c}\text { atrazine } \\
3.0\end{array}$} & \multirow[b]{2}{*}{$\begin{array}{c}\text { cyanazine } \\
2.6\end{array}$} & \multirow[b]{2}{*}{$\begin{array}{c}\text { desethylatrazine } \\
0.46\end{array}$} & \multirow[b]{2}{*}{$\begin{array}{c}\text { desisopropylatrazine } \\
0.30\end{array}$} & \multirow[b]{2}{*}{$\begin{array}{c}\text { metolachlor } \\
5.5\end{array}$} \\
\hline $\begin{array}{l}\text { distance }^{a} \\
(\mathrm{~m})\end{array}$ & $\begin{array}{l}\operatorname{depth}^{a} \\
\text { (m) }\end{array}$ & & & & & & \\
\hline \multirow[t]{4}{*}{5} & 3 & 0.20 & 0.66 & 0.21 & 0.22 & 0.13 & 0.43 \\
\hline & 4 & 0.44 & 2.2 & 0.64 & 0.31 & 0.14 & 0.87 \\
\hline & 6 & 0.38 & 1.3 & 0.85 & 0.25 & 0.12 & 1.4 \\
\hline & 9 & $\mathrm{ND}^{b}$ & 0.19 & ND & 0.16 & ND & ND \\
\hline \multirow[t]{4}{*}{10} & 3 & ND & 0.44 & ND & 0.32 & 0.11 & ND \\
\hline & 6 & 0.50 & 1.5 & 0.85 & 0.25 & 0.13 & 1.5 \\
\hline & 9 & ND & 0.23 & ND & 0.15 & ND & ND \\
\hline & 14 & ND & 0.10 & ND & 0.13 & ND & ND \\
\hline \multirow[t]{3}{*}{20} & 3 & ND & 0.47 & ND & 0.22 & 0.11 & ND \\
\hline & 6 & 0.10 & 0.39 & ND & 0.16 & 0.08 & 0.19 \\
\hline & 9 & ND & 0.21 & ND & 0.14 & 0.06 & ND \\
\hline \multirow[t]{3}{*}{30} & 3 & ND & 0.41 & ND & 0.22 & 0.10 & ND \\
\hline & 6 & ND & 0.20 & ND & 0.12 & 0.05 & ND \\
\hline & 9 & ND & 0.16 & ND & 0.12 & ND & ND \\
\hline \multirow[t]{3}{*}{50} & 3 & ND & 0.47 & ND & 0.12 & 0.06 & ND \\
\hline & 6 & ND & 0.24 & ND & 0.09 & ND & ND \\
\hline & 9 & ND & 0.21 & ND & 0.12 & ND & ND \\
\hline
\end{tabular}

and $1.3 \mu \mathrm{g} / \mathrm{L}$, respectively, and the river's mean daily discharge was $205 \mathrm{~m}^{3} / \mathrm{s}$ (13). These two periods are compared because at both periods the river had receded to about $60-65 \%$ of the maximum mean daily discharge of the respective events.

Results showed that alachlor concentrations in river water decreased $57 \%$ [ $(0.37-0.86) / 0.86]$, cyanazine concentrations decreased $23 \%$ [ $(0.67-0.87) / 0.87]$, and metolachlor concentrations decreased $8 \%$ [(1.2-1.3)/1.3]. In contrast, atrazine concentration increased $280 \%$ [(3.81.0)/1.0].

The reason(s) for increasing atrazine concentrations in river water during increased streamflow can be speculated. Due to historical and on-going herbicide applications, it is possible that a substantial amount of atrazine may have been accumulated in the watershed: in the soils, drain tiles, tributaries, river bottom, and riverbanks (4). In this paper, this phenomenon is referred to as "basin storage". This basin storage may be similar to that reported in a study of nitrate transport in the Raccoon River Basin, Iowa (15). The nitrogen fertilizer that was applied to agricultural fields in that basin for two seasons remained in the soil due to a severe drought. In subsequent rainstorms, nitrate nitrogen was flushed from basin storage into the Raccoon River. Large nitrate-nitrogen concentrations (greater than $10 \mathrm{mg} / \mathrm{L}$ ) occurred in the river, even though annual nitrogen application had remained the same as in the previous drought years.

A large basin storage of atrazine, compared with other herbicides, in the Cedar River Basin is possible for the two reasons. First, atrazine is the most extensively used herbicide for corn and soybean production during the past 30 years, and consequently, it is likely that atrazine has been accumulated in the watershed in a larger quantity than others $(1,3,6,16-18)$. Second, atrazine is known to be more persistent in soil than alachlor, cyanazine, and metolachlor (19) because the atrazine degradation process in soils is generally slow. For example, Klaine et al. (20) reported that the half-life for atrazine in the top $10 \mathrm{~cm}$ of soil was $21.5 \mathrm{~d}$. Mullaney et al. (21) found that pesticide residence time in the soil was inversely related to the soil organic content. A fact sheet on atrazine prepared by the U.S. Environmental Protection Agency (16) reports atrazine half-lives ranging from $146 \mathrm{~d}$ in loam soil to $660 \mathrm{~d}$ in 

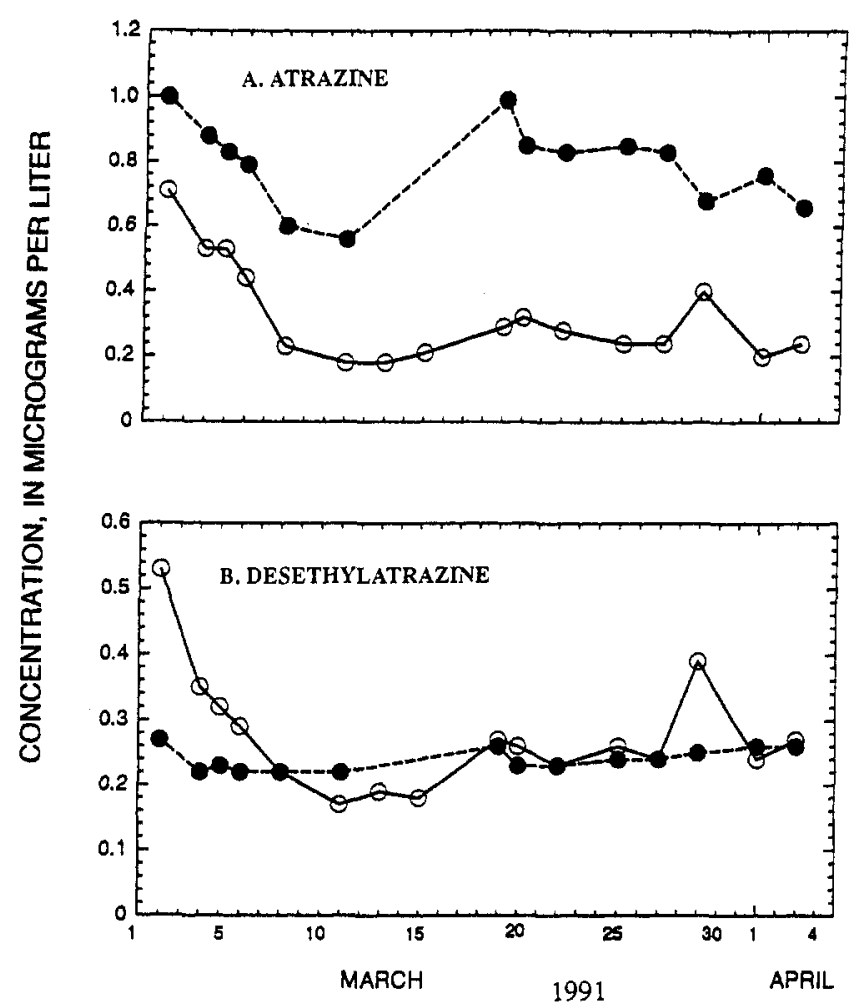

\section{EXPLANATION \\ O- RIVER WATER \\ - Well water}

Figure 6. Concentrations of atrazine and desethylatrazine in river water and well water (approximately $12 \mathrm{~m}$ from the river and screened at a depth of $4 \mathrm{~m}$ ) during flooding, Mar 2-Apr 3, 1991.

anaerobically incubated sandy clay. Nair and Schnoor (22) reported that atrazine mineralization rates for the ring and isopropyl side chain of the compound were 140 and 10 times slower, respectively, for anaerobic conditions than for aerobic conditions.

Bank storage is part of basin storage. The conditions at the Cedar River research site were generally favorable for herbicide interchange between riverbanks and the river because of the mostly sandy materials, low organic content, and low clay content. Of 24 alluvial aquifer samples collected, organic carbon contents ranged from 0.05 to $2.5 \%$, with a geometric mean value of $0.14 \%$. In addition, the alluvial aquifer is generally under anaerobic conditions (e.g., well water below $3 \mathrm{~m}$ depth generally contained 1 $\mathrm{mg} / \mathrm{L}$ or less dissolved oxygen) and with relatively low temperature (approximately $10^{\circ} \mathrm{C}$ ).

Evidence of Herbicide Bank Storage. Results of herbicide concentrations in river water and well water are summarized in Table 2. Herbicide concentrations in well water varied according to herbicide compounds, well depth, and distance from river's edge. Among four herbicides, elevated atrazine concentrations were detected in wells as distant as $50 \mathrm{~m}$ from the river's edge, whereas elevated alachlor, cyanazine, and metolachlor concentrations were detected only as distant as 20,10 , and $20 \mathrm{~m}$. During March 1990 high streamflow, elevated atrazine concentrations were detected at depths of 3-9 m below the land surface. During May high streamflow, the largest concentrations of atrazine were detected primarily $3-6 \mathrm{~m}$ below the land surface.

There is an important question that needs to be addressed: Of the same new water, why did atrazine infiltrate more into the aquifer than alachlor, cyanazine,
Table 2. Evidence of Herbicide Bank Storage Using Results of Herbicide Concentrations $(\mu \mathrm{g} / \mathrm{L})$ in Wells Apparently Not Affected $a$ and Affected $b$

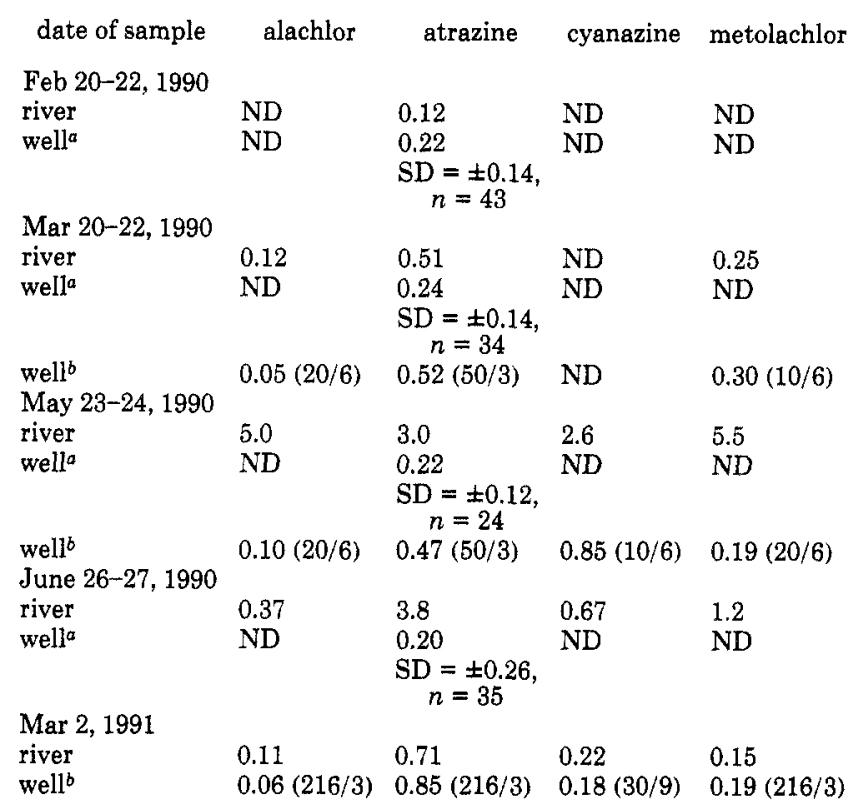

a Wells apparently not affected by bank storage, expressed by mean herbicide concentration, standard deviation, and number of samples. ${ }^{b}$ Wells apparently affected by bank storage, expressed by herbicide concentration in the farthest well affected (distance from the river's edge, $\mathrm{m} /$ depth, $\mathrm{m}$ ). ${ }^{c} \mathrm{SD}$, standard deviation, $n$, number of samples. ND, not detected.

and metolachlor? The reason may be that during high streamflows, atrazine in the river water peaked early, whereas concentrations of alachlor, cyanazine, and metolachlor peaked late. For example, on May 10, concentrations of alachlor, atrazine, cyanazine, and metolachlor in river water were $1.7,6.2,<0.20$, and $0.42 \mu \mathrm{g} / \mathrm{L}$, respectively. During May 23-24, concentrations of these herbicides were $5.0,3.0,2.6$, and $5.5 \mu \mathrm{g} / \mathrm{L}$, respectively (Table 1). During May 9 and 10 , the hydraulic gradient was toward the aquifer to allow the larger atrazine concentration to infiltrate into the aquifer (Figure 5). Concentrations of other herbicides were larger during May 23 and 24, at the time when the hydraulic gradient was toward the river (Figure 5).

Other herbicides, as part of new water, also could have infiltrated $50 \mathrm{~m}$ into the aquifer. However, they might have been at concentrations below detection limit and could not be confirmed. Especially for cyanazine, the detection limit was $0.2 \mu \mathrm{g} / \mathrm{L}$; the cyanazine bank storage value might have been larger if the detection level were $0.05 \mu \mathrm{g} / \mathrm{L}$ as that of other herbicides. The fates of these herbicides, such as adsorption, biouptake, and degradation in the aquifer, may be different from that of atrazine and result in slowing down their infiltration (19-22).

If river water contains the same herbicide concentration as the background concentration in the aquifer, herbicide bank storage cannot be quantified because the boundary of the new water and the old water cannot be delineated. During high streamflow in spring runoff, the hydraulic gradient and the large herbicide concentrations in river water combined to transport herbicide into the riverbank and alluvium and resulted in substantial herbicide bank storage.

Quantification of Herbicide Bank Storage. In this study, herbicide bank storage is defined as the process of herbicide temporarily stored in an alluvial aquifer as a 


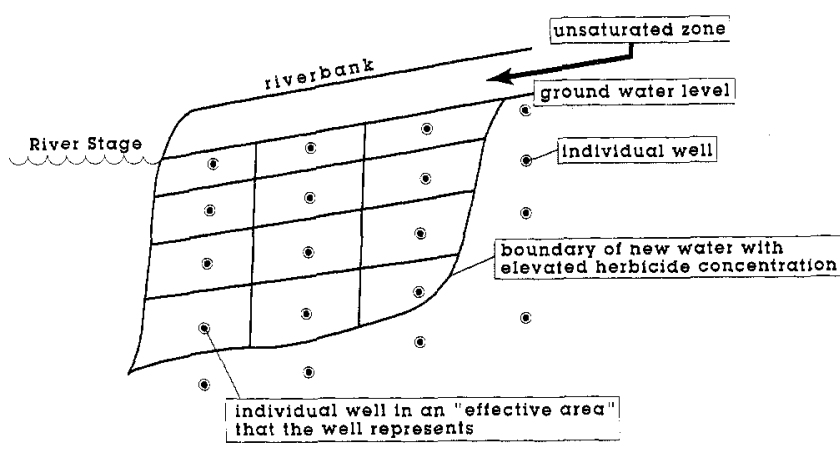

Figure 7. Conceptual model of herbicide bank storage.

Table 3. Herbicide Bank Storage Values $(\mathrm{mg} / \mathrm{m}$ ) during High Streamflow, Expressed as Herbicide Concentrations Multiplied by Effective Area and a 25\% Porosity

date of sample alachlor atrazine cyanazine metolachlor

Mar 20-22, 1990 1.7 79 0 11 4.0 May 23-24, 1990 7.1 54 19

result of lateral infiltration through the riverbank. By assuming a piston-flow model, all detectable herbicides in the infiltrating water are considered. The boundary of infiltration is identified by herbicide concentrations elevated above background. The river bottom may also store herbicides (8), but is not considered here. Processes of adsorption/desorption of dissolved herbicides are considered minimal. Under these conditions, herbicide bank storage can be quantified by summation of herbicide concentration multiplied by an "effective area" (for which that concentration is assumed representative) and an assumed porosity of 0.25 , as in the following equation:

$$
\mathrm{HBS}=\sum x y z f
$$

where HBS is the herbicide bank storage; $x$ is the herbicide concentration; $y$ is the "effective length" of a well (m); $z$ is the "effective depth" of a well $(\mathrm{m})$; and $f$ is the porosity. With conversion factors of $1000 \mathrm{~L} / \mathrm{m}^{3}$ and $1 \mathrm{mg} / 1000 \mu \mathrm{g}$, the unit of measurement for herbicide bank storage becomes milligrams per meter. The result expresses the amount of herbicide temporarily stored in a riverbank of $1 \mathrm{~m}$ width, extending from the river's edge into the alluvium. The conceptual model of herbicide bank storage is depicted in Figure 7, indicating the effective area that a well represents.

In eq 1 , the effective length of a well $10 \mathrm{~m}$ from the river's edge and located between two horizontally adjacent wells ( 5 and $20 \mathrm{~m}$ from the river's edge) may be calculated. The boundaries of the 10-m well's effective length are assumed to be the midpoint between two adjacent wells. Therefore, the effective length of the $10-\mathrm{m}$ well is $7.5 \mathrm{~m}$, computed by $0.5 \times[(10-5)+(20-10)]$. The top $1-\mathrm{m}$ alluvium is assumed to be unsaturated and is excluded from the computation. Thus, the effective depth of this well screened at $3 \mathrm{~m}$ below land surface is $2.5 \mathrm{~m}$, computed by $0.5 \times[(3-1)+(6-3)]$, taking into consideration that the next deeper well was screened at $6 \mathrm{~m}$.

The alachlor bank storage value during May 23 and 24, 1990, can be calculated using data in Table 1 as follows: $(0.20 \mu \mathrm{g} / \mathrm{L} \times 7.5 \mathrm{~m} \times 1.5 \mathrm{~m}+0.44 \mu \mathrm{g} / \mathrm{L} \times 7.5 \mathrm{~m} \times 1.5 \mathrm{~m}$ $+0.38 \mu \mathrm{g} / \mathrm{L} \times 7.5 \mathrm{~m} \times 2.5 \mathrm{~m}+0.50 \mu \mathrm{g} / \mathrm{L} \times 7.5 \mathrm{~m} \times 3.0$ $\mathrm{m}+0.10 \mu \mathrm{g} / \mathrm{L} \times 10 \mathrm{~m} \times 3.0 \mathrm{~m}) \times 0.25=7.1 \mathrm{mg} / \mathrm{m}$. Calculated herbicide bank storage values are given in Table 3. During March 20-22, 1990, the storage values for alachlor, atrazine, and metolachlor were $1.7,79$, and 4.0 $\mathrm{mg} / \mathrm{m}$, respectively. During May 23 and 24, 1990, the storage values for alachlor, atrazine, cyanazine, and metolachlor were $7.1,54,11$, and $19 \mathrm{mg} / \mathrm{m}$, respectively.

These values represent conservative estimates of herbicide bank storage. Factors such as herbicide concentrations below detection limits, microbial degradation, and adsorption/desorption in the aquifer add uncertainty to these values. Another factor affecting these values is the imprecise boundary of new water with elevated herbicide concentrations, as depicted in Figure 7. This factor, however, is relatively minor and unlikely to cause a major change of the values. The reason is that herbicide concentration near the boundary is near to the background concentration and its effect on herbicide bank storage value (based on equation 1) is small.

Herbicide bank storage values varied according to the herbicide compounds and hydrologic events. According to Table 3, atrazine bank storage values decreased from March to May, whereas other herbicide bank storage values increased. This discrepancy is the result of at least the two following factors. First, the hydraulic gradient for March was more consistently from the river toward the aquifer than for May (Figures 3 and 5). More atrazine infiltrated the alluvium in the March runoff as atrazine was detected in water from all wells screened at 3-9 m below surface from wells near the river to the $50-\mathrm{m}$ well. In contrast, atrazine was detected in May 1990 primarily at 3-6 $\mathrm{m}$ below surface (Table 1). The larger atrazine plume in the alluvial aquifer during the March runoff would result in a larger bank storage value than would the May runoff, overcoming the fact that atrazine concentrations in river water were larger in May as compared to those in March 1990 (Table 2). Second, alachlor, cyanazine, and metolachlor are less persistent in soils than atrazine according to literature (19). The larger concentrations of these herbicides in river water in May than in March 1990 (Table 2), possibly due to more recent applications, was the reason that these herbicide bank storage values were larger in May than in March 1990. Other factors such as different degradation rates among herbicides could affect the herbicide bank storage values.

Significance of Herbicide Bank Storage. Herbicide bank storage, like water bank storage, results from the interchange between a stream and its alluvial aquifer. The riverbank and alluvium act as temporary reservoirs for holding and releasing herbicides, a dynamic and reversible process. Water movement and associated herbicide interchange are driven by hydraulic gradient.

This research suggests a method to quantify herbicide bank storage. Similar method(s) could be developed to quantify bank storage of other contaminants such as toxic metals, polychlorinated biphenyls, and polynuclear aromatic hydrocarbons. Herbicide storage in a riverbed can occur at low and high streamflow (8), whereas herbicide storage in a riverbank occurs during high streamflow and flood. Measurement of herbicide storage in the riverbed is more difficult than that in the alluvial aquifer during the dangerous high streamflow and flood periods.

Although this approach could be used to compare herbicide interchange of different sites, it is important to note that the herbicide bank storage value is dependent on various factors such as aquifer properties, herbicide concentration and properties, hydraulic gradient, and duration of hydrologic events $(20-25)$. The comparison of herbicide bank storage values from different sites should take these factors into consideration. By way of analogy, 
it is possible to compare volumes of water stored in different reservoirs, but the volumes of water should not be used to infer the size, shape, or depth of reservoirs.

\section{Summary}

During 1990 and 1991, two high streamflows and two floods occurred at the study site. During the first high streamflow (March 1990), herbicide bank storage of alachlor, atrazine, and metolachlor was evident in well water as distant as 20,50 , and $10 \mathrm{~m}$ from the river's edge, respectively. During the second high streamflow (May 1990), herbicide bank storage of alachlor, atrazine, cyanazine, and metolachlor was evident in well water as distant as $20,50,10$, and $20 \mathrm{~m}$ from the river's edge, respectively. Herbicide bank storage can be quantified by multiplying herbicide concentration by effective area represented by a well and an assumed porosity. Herbicide bank storage values can be used to compare results among different herbicides and under different hydrologic conditions.

\section{Acknowledgments}

This research was funded by the Toxic Substances Hydrology Program of the U.S. Geological Survey. We thank James Snyder for his cooperation in providing access to his land for installation and monitoring of the observation wells. The use of trade names is for identification purpose only and does not constitute endorsement by the U.S. Geological Survey.

Author-Supplied Registry Numbers: Alachlor, 1597260-8; atrazine, 1912-24-9; cyanazine, 21725-46-2; desethylatrazine, 6190-65-4; desisopropylatrazine, 1007-28-9; metolachlor, 51218-45-2.

\section{Literature Cited}

(1) Iowa State University. A survey of pesticides used in Iowa crop production in 1990; PM 1441; University Extension: Ames, IA, 1991.

(2) Squillace, P. J.; Engberg, R. A. Surface-water quality of the Cedar River Basin, Iowa-Minnesota, with emphasis on the occurrence and transport of herbicides, May 1984 through November 1985. U.S. Geol. Surv. Water-Resour. Invest. 1988, No. 88-4060.

(3) Goolsby, D. A.; Coupe, R. C.; Markovchick, D. J.Distribution of selected herbicides and nitrate in the Mississippi River and its major tributaries, April through June 1991. U.S. Geol. Surv. Water-Resour. Invest. 1991, No. 91-4163.

(4) Squillace, P. J.; Thurman, E. M. Environ. Sci, Technol. $1992,26,538-545$.

(5) Freeze, A. Q.; Cherry, J. A. Groundwater; Prentice-Hall: Englewood Cliffs, NJ, 1979.

(6) Thurman, E. M.; Goolsby, D. A.; Meyer, M. T.; Kolpin, D. W. Environ. Sci. Technol. 1991, 25, 1794-1796.
(7) Squillace, P. J.; Thurman, E. M.; Fischer, E. E.; Soenksen, P. J. Sources of atrazine, desethylatrazine, metolachlor in a selected reach of the Cedar River, Iowa, during base-flow condition. U.S. Geol. Surv. Water-Resour. Invest. 1991, No. 91-4034, 189-194.

(8) Squillace, P. J.; Thurman, E. M.; Furlong, E. Water Resour. Res. 1993, 29, 1719-1729.

(9) Thurman, E. M.; Meyer, M.; Pomes, M.; Perry, C. A. Anal. Chem. 1990, 62, 2043-2048.

(10) Meyer, M. T.; Mills, M. S.; Thurman, E. M. J. Chromatogr. $1990,629,55-59$.

(11) Anderson, T. A.; Guthrie, E. A.; Walton, B. T. Environ. Sci. Technol. 1993, 27, 2630-2636.

(12) Nair, D. R.; Burken, J. G.; Licht, L. A.; Schnoor, J. L. J. Environ. Eng. 1993, 119, 842-854.

(13) O'Connell, D. J.; Liszewski, M. J.; Lambert, R. B.; Mathews, W. J. Water resources data-Iowa-water year 1990. U.S. Geol. Surv. Water-Data Rep. 1990, No. 91-4034.

(14) Schulmeyer, P. M. Relation of selected water-quality constituents to river stage in the Cedar River, IA. U.S Geol. Surv. Water-Resour. Invest. 1991, No. 91-4034, 227231.

(15) Lucey, K. J.; Goolsby, D. A. J. Environ. Qual. 1993, 22, $38-46$.

(16) U.S. Environmental Protection Agency. Pesticide fact sheet-Atrazine (Draft); U.S. EPA: Washington, DC, Nov 1991.

(17) Nielsen, E. D.; Lee, L. K. The magnitude and costs of groundwater contamination from agricultural chemicals-A national perspective; U.S. Department of Agriculture Staff Report AGES870318; Washington, DC, 1987.

(18) Hartzler, R.; Wintersteen, W. A survey of pesticides used in Iowa crop production in 1990; PM 1441; Iowa State University: Ames, IA, 1991.

(19) Nash, R. G. In Environmental Chemistry of Herbicides; Grove R., Ed.; CRC Press: Boca Raton, FL, 1988; pp 131169.

(20) Klaine, S. J.; Hinman, M. L.; Winkelmann, D. A.; Sauser, K. R.; Martin, J. R.; Moore, L. W. Environ. Toxicol. Chem. 1988, 7, 609-614.

(21) J. R.; Melvin, R. L.; Adamik, J. T.; Robinson, B. R.; Frink, C. R. Pesticides in ground water, soil, and unsaturatedzone sediments at selected sites in Connecticut; Connecticut Water Resources Bulletin 42; Hartford, CT, 1991.

(22) Nair, D. R.; Schnoor, J. L. Environ. Sci. Technol. 1992, 26, 2298-2300.

(23) Helling, C. S.; Gish, T. V. In Evaluation of pesticides in ground water; Garner, W. A., Honeycutt, R. C., Nigg, H. N., Eds.; ACS Symposium Series 315; American Chemical Society: Washington, DC, 1986; pp 14-38.

(24) Poinke, H. B.; Glotfelty, D. W. Chemosphere 1990, 21, 813822.

(25) Wehtje, G.; Mielke, L. N.; Leavitt, J. R. C.; Scheppers, J. S. J. Environ. Qual. 1984, 13, 507-513.

Received for review March 16, 1994. Revised manuscript received August 16, 1994. Accepted August 24, 1994.

- Abstract published in Advance ACS Abstracts, October 1, 1994. 